\title{
Temporal metabolic response and mRNA COVID-19 vaccination
}

\author{
Pathum Sookaromdee ${ }^{1} \cdot$ Viroj Wiwanitkit ${ }^{2}$
}

Received: 31 August 2021 / Accepted: 13 September 2021 / Published online: 18 September 2021

(c) The Japanese Society of Nuclear Medicine 2021

Dear editor, we would like to share ideas on the publication "Temporal metabolic response to mRNA COVID-19 vaccinations in oncology patients [1]." Advani et al. concluded that "Consideration should be given to performing FDG PET at least 2 weeks after the COVID-19 vaccine. [1]." This report can confirm that both immunological and metabolic responses occurred at lymph node following COVID-19 mRNA vaccination. Waiting might be a good practice. However, the problem might still exist after 2-week period of waiting and it is sometimes not possible to have a long waiting. To avoid interference in medical imaging for cancerous case, in a recent report, it is recommended for "administering the vaccine in the arm contralateral to a unilateral cancer [2]."

\section{Declarations}

Conflict of interest None.

\section{References}

1. Advani P, Chumsri S, Pai T, Li Z, Sharma A, Parent E. Temporal metabolic response to mRNA COVID-19 vaccinations in oncology patients. Ann Nucl Med. 2021. https://doi.org/10.1007/ s12149-021-01675-8.

2. McIntosh LLJ, Bankier AA, Vijayaraghavan GR, Licho R, Rosen MP. COVID-19 vaccination-related uptake on FDG PET/CT: an emerging dilemma and suggestions for management. AJR Am J Roentgenol. 2021. https://doi.org/10.2214/AJR.21.25728.

Publisher's Note Springer Nature remains neutral with regard to jurisdictional claims in published maps and institutional affiliations.

Pathum Sookaromdee

pathumsook@gmail.com

1 Private Academic Consultant, Bangkok, Thailand

2 Dr DY Patil University, Pune, India 